[RAdiocarbon, Vol. 14, No. 1, 1972, P. 195-222]

\title{
UNIVERSITY OF MICHIGAN RADIOCARBON DATES XV
}

\author{
H. R. CRANE and JAMES B. GRIFFIN
}

The University of Michigan, Ann Arbor, Michigan

The following is a list of dates obtained since the compilation of List XIV, and the method is essentially the same. Two $\mathrm{CO}_{2}-\mathrm{CS}_{2}$ Geiger counter systems were used. Equipment and counting techniques have been described elsewhere (Crane, 1961). Dates and estimates of error in this list follow the practice recommended by the International Radiocarbon Dating Conference of 1962 and 1965, in that (a) dates are computed on the basis of the Libby half-life, 5570 yr, (b) A.D. 1950 is used as the zero of the age scale, and (c) the errors quoted are the standard deviations obtained from the number of counts only. In Michigan date lists up to and including VII, we quoted errors at least twice as great as the statistical errors of counting, to take account of other errors in the over-all process.

This date list represents the conclusion of the Michigan series. Operation of the laboratory ended in January 1971, for reasons of rising costs and shrinking support funds.

We wish to acknowledge the help of Patricia Dahlstrom in preparing chemical samples and John D. Speth, Roberta Pennypacker, Steve Plog, Robert M. Schacht, R. Ingrid Christensen, and Dale D. Brodkey in preparing the descriptions. We are also indebted to the editors of Radiocarbon for their assistance in improving our manuscripts.

\section{GEOLOGIC SAMPLES}

\section{M-2079. Bagotville Bog, Quebec, Canada}

Peat from Bagotville Bog ( $48^{\circ} 21^{\prime} 30^{\prime \prime} \mathrm{N}$ Lat, $70^{\circ} 56^{\prime} 50^{\prime \prime}$ W Long), Quebec, Canada. Sample taken with Hiller borer from bottom of peat bog $4 \mathrm{~m}$ thick, underlain by marine clay. Alt. $127.8 \mathrm{~m}$ above present sea level (LaSalle and Rondot, 1967). Coll. 1967 and subm. by Pierre LaSalle, Quebec Dept. Nat. Resources, Quebec, Canada. Comment (P.L.): date agrees well with other dates in area on marine shells, wood, marl, plant debris, and basal layer of bog (LaSalle, 1968, p. 27).

\section{M-1927. Houghton County, Michigan}

$870 \pm 110$

Podzol from (47 $08^{\prime} \mathrm{N}$ Lat, $88^{\circ} 42^{\prime} \mathrm{W}$ Long), SW 1/4, SW 1/4, Sec. 25, Stanton Twp., Houghton Co., Michigan (Lietzke and Whiteside, 1967; Miller, 1966). Sample from $B_{21}$ hir horizon at depth +12.7 to 22.8 cm. Coll. 1966 by E. P. Whiteside; subm. by M. M. Miller, Michigan State Univ., East Lansing. Comment (M.M.M. and D.L.): date represents mean time or age of organic carbon in this soil profile. Other dates from surface horizons (USDA-SCS, 1960) reveal ages from 100 to $400 \mathrm{yr}$, while other dates of similar subsurface horizons vary from 900 to 1100 yr. Dates indicate turnover rate of organic matter in soils, and that 
humus material of spodic horizons is relatively resistant to further decomposition.

\section{M-1975. Gastineau Channel, Alaska}

$1330 \pm 130$

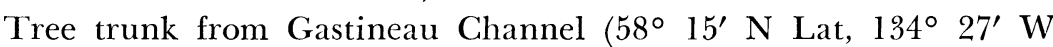
Long), Juneau B-2 quad., Alaska, between Juneau and Salmon Creek along Glacier Hwy. Alt. ca. $25.4 \mathrm{~m}$. Part of overridden tree trunk in situ on nonweathered blue-gray till. Coll. and subm. by M. M. Miller. Comment (M.M.M.):if sample is of glacial origin, date should be much older. Stratigraphy suggests sample should antedate 7000 в.P.

\section{M-1981. Taylor Valley, Antarctica}

Muscle of mummified seal (Leptonychotes weddelli), weathered side of thorax, at Taylor Valley $\left(77^{\circ} 40\right.$ to $43^{\prime} \mathrm{S}$ Lat, $162^{\circ} 30$ to $45^{\prime}$ E Long), at foot of Suess glacier, Lake Bonney, and Nussbaum Riegal, Antarctica. Exped. supported by NSF Grant G. B. 2647. Coll. 1966 by T. Blair; subm. by M. A. Marini, M. F. Orr, and E. L. Coe, Northwestern Univ., Evanston, Illinois. Comment (E.L.C.): date agrees reasonably with previous date on same animal (M-1919: $2045 \pm 140$ B.P., R., v. 10, 1968, p. 66). Difference exceeds error slightly. Antarctic samples seem to date ca. 600 yr older than they should (cf. M-1920, a seal known to be dead $<1$ yr dated $615 \pm 100$ B.P., R., 1968, v. 10, p. 66).

\section{Grand Sable Dunes series, Michigan}

Wood and partially carbonized wood from Grand Sable Dunes $\left(46^{\circ}\right.$ $40^{\prime} \mathrm{N}$ Lat, $86^{\circ} 01^{\prime} \mathrm{W}$ Long), SE 1/4 of Sec. 2 T.49N, R.14W, Alger Co., Michigan. Coll. 1968 by T. R. Detwyler and Maurice Grolier; subm. by T. R. Detwyler, Dept. Geog., Univ. of Michigan.

\section{M-2129. Sample GSD 6-3-68-1}

$320 \pm 100$

In E-most N-S valley of dunes area. Partially carbonized wood (Pinus banksiana?) from stump protruding $22.9 \mathrm{~cm}$ above present dune surface. Stump rooted in and below organic-rich paleosol 81.3 to $89 \mathrm{~cm}$ below surface. Rooted several $\mathrm{m}$ above top of outwash terrace(?) at ca. 220 to $221 \mathrm{~m}$ alt. Stump is $\mathrm{W}$-most of $>12$ similar stumps nearby, ca. $68.7 \mathrm{~m} \mathrm{~W}$ of dune, $18.3 \mathrm{~m} \mathrm{~N}\left(10^{\circ} \mathrm{E}\right)$ of Sable Creek.

\section{M-2130. Sample GSD 6-3-68-2}

A.D. 1450

$500 \pm 100$

In 2nd N-S valley from $\mathrm{E}$ edge of dunes area. Wood (Pinus banksiana?); $17.8 \mathrm{~cm}$ long piece of bole 35.6 to $53.4 \mathrm{~cm}$ above dune surface. Sampled bole stood $114.4 \mathrm{~cm}$ above ground, $16.5 \mathrm{~cm}$ diam. Tree (one of many similar) is ca. $27.5 \mathrm{~m} \mathrm{E}$ of axis of valley bottom, ca. $25 \mathrm{~m} \mathrm{~W}$ of dune crest, $8.25 \mathrm{~m}$ higher than ground at base of log. Within $61 \mathrm{~m}$ $\mathrm{S}$ of escarpment overlooking Lake Superior; alt. ca. $221 \mathrm{~m}$.

General Comment (T.R.D.): these 2 samples indicate dune ridges E Grand Sable Dunes moved E-ward during past several hundred yr at a 
mean rate between .076 and $.24 \mathrm{~m}$ per yr. Rate is consistent with contemporary rates. Pollen in paleosols of rooted trees was not analyzed (Grolier and Detwyler, 1970).

\section{Frains Lake Core series, Michigan}

Clay gyttja from Frains Lake $\left(42^{\circ} 20^{\prime} \mathrm{N}\right.$ Lat, $83^{\circ} 37^{\prime} \mathrm{W}$ Long), T.2S, R.7E, Sec. 9, Washtenaw Co., Michigan, $17 \mathrm{~m}$ core. Dates are being used to determine sedimentation rates in central lake basin, from which accumulation rates of fossil pollen and cladocera and absolute times of major changes both within lake and in communities surrounding lake are being calculated. Coll. 1968 by Linda Brubaker, M. B. Davis, W. C. Kerfoot, and Ted Calendar; subm. by W. C. Kerfoot, Great Lakes Research Div., Univ of Michigan.

\section{M-2297. Sample A}

$850 \pm 200$

Clay gyttja from 3.00 to $3.08 \mathrm{~m}$ below mud-water interface.

\section{M-2298. Sample B}

$1740 \pm 140$

Gyttja from 5.77 to $5.87 \mathrm{~m}$ below mud-water interface.

\section{M-2299. Sample $C$}

$4620 \pm 190$

Gyttja from 7.81 to $7.91 \mathrm{~m}$ below mud-water interface.

\section{M-2300. Sample D}

$8000 \pm 300$

Gyttja from 9.96 to $10.06 \mathrm{~m}$ below mud-water interface.

\section{M-2301. Sample E}

$9600 \pm 330$

Gyttja from 10.50 to $10.60 \mathrm{~m}$ below mud-water interface.

\section{M-2302. Sample F}

$9960 \pm 350$

Clay gyttja from 10.90 to $11.00 \mathrm{~m}$ below mud-water interface.

General Comment (W.C.K.): dates reveal initially rapid clay sedimentation (bottom $4 \mathrm{~m}$ ) easing into slow organic sedimentation, abruptly increased during last $150 \mathrm{yr}$ by rapid accumulation of silt, clay, and organic matter in central basin following forest clearance. Other dates from core are $810 \pm 90$ : A.D. 1140 (I-5224) from depth 3.89 to $3.96 \mathrm{~m}$, and $1240 \pm 90:$ A.D. 710 (I-5225) from depth 4.68 to $4.78 \mathrm{~m}$.

\section{M-2335. Simmons Reef, Michigan}

$2800 \pm 150$

850 B.C.

Stump( Fraxinus nigra) id. by Suzanne Harris, Mus. Anthropol., Univ. of Michigan, from Simmons Reef (45 $54^{\prime} \mathrm{N}$ Lat, $85^{\circ} 13^{\prime} \mathrm{W}$ Long), N of Beaver I. Sample from bottom of Lake Michigan at depth $5.5 \mathrm{~m}$ (161 m A.T.). Coll. 1969 by R. F. Anderson; subm. by J. L. Hough, Dept. 
Meteorol. and Oceanog., Univ. of Michigan. Comment (J.L.H.): site, uplifted $58 \mathrm{~m}$ since Lake Algonquin times, should have been a shoreline at elev. ca. $159 \mathrm{~m} \mathrm{A.T.} \mathrm{during} \mathrm{rise} \mathrm{of} \mathrm{lake} \mathrm{level} \mathrm{from} \mathrm{Chippewa} \mathrm{low}$ stage toward Nipissing stage. Age should be nearly 7000 yr B.P.

\section{M-2337. Straits of Mackinac, Michigan}

$8150 \pm 300$

Tree roots (Tsuga, probably $T$. canadensis) id. Suzanne Harris, from Straits of Mackinac (45 49 $09^{\prime \prime}$ N Lat, 84 $43^{\prime} 50^{\prime \prime}$ W Long), NW of $\mathrm{N}$ bridge tower, Michigan. Sample from lake bottom, depth $37.2 \mathrm{~m}$ (199 m A.T.). Coll. 1969 by L. H. Somers; subm. by J. L. Hough. Comment (J.L.H.): site, uplifted $55 \mathrm{~m}$ since Lake Algonquin times, should have been shoreline elev. ca. $119 \mathrm{~m} \mathrm{A.T.} \mathrm{during} \mathrm{rise} \mathrm{of} \mathrm{lake} \mathrm{level} \mathrm{from}$ Chippewa-Stanley low stage toward Nipissing stage. A previous date of tree stump from same location is $9780 \pm 330$ (M-1996: R., 1970, v. 12, p. 163).

\section{Mile 47 Bog series, Canada}

Peat, clay, and marly material from Mile 47 Bog $\left(59^{\circ} 43^{\prime} 30^{\prime \prime} \mathrm{N}\right.$ Lat, $133^{\circ} 44^{\prime} 50^{\prime \prime}$ W Long), British Columbia, Canada. Sampling site $91.5 \mathrm{~m} \mathrm{SW}$ from Atlin Hwy. Coll. 1967 and subm. by J. H. Anderson, Dept. Geol., Michigan State Univ., East Lansing.

M-2050. Sample No. 97

$3200 \pm 160$

Taken with Hiller sampler, from transition zone at base of peat. Upper and lower mixed. Elev.: $777 \mathrm{~m}$; depth: 135 to $145 \mathrm{~cm}$. Upper portion: peat-fine, fibrous, no stems. HCL reaction mild. Few shells present. Lower portion: marly material, containing many shells, light color. HCL reaction strong.

M-2051. Sample No. 98

$$
\begin{aligned}
\text { Organic: }: & 8600 \pm 330 \\
& 6650 \text { B.c. } \\
\text { Inorganic: }: & 8670 \pm 900 \\
& 6720 \text { B.c. } \\
& \text { Error } 3 X
\end{aligned}
$$

Taken with Davis sampler, from upper level blue-gray glacial lake clay at transition of overlying material. Elev. ca. $777 \mathrm{~m}$. Upper portion: particulate material, very fine, clayey, homogeneous, dark gray-blue color. Shell moderately abundant. HCL reaction moderate. Plant remains are fine, fibrous, particulate, moderately abundant. Lower portion: glacial lake clay, blue-gray. Shells few. HCL reaction moderate. No plants, but few small whitish inclusions of same consistency as clayey matrix.

\section{M-2054. Piddlin' Pond Bog, Canada}

$4160 \pm 180$

2210 B.c.

Peat from Piddlin' Pond Bog (59 40' $05^{\prime \prime}$ N Lat, $133^{\circ} 42^{\prime} 30^{\prime \prime} \mathrm{W}$ Long), British Columbia, Canada, near Atlin Hwy. W at Milepost 52, 384 
$\mathrm{m} \mathrm{W}$ of post, elev. ca. $732 \mathrm{~m}$. From transition zone at base of peat mixed in bog. Coll. 1967 and subm. by J. H. Anderson. Upper portion of sample: peat-fine fibrous to particulate, few stem pieces $>1 \mathrm{~cm}$ long, few recognizable leaf fragments. Shells few, well-preserved. No HCL reaction except shell. Lower portion: peat similar to upper but more particulate, few plant parts recognizable, shell abundant. Black stem sec. gritty (ashy) when crushed.

\section{Mile 16 Bog site series, Canada}

Organic material from Mile 16 Bog site $\left(60^{\circ} 08^{\prime} 50^{\prime \prime} \mathrm{N}\right.$ Lat, $133^{\circ} 49^{\prime}$ 24" W Long), British Columbia, Canada, taken with Davis sampler from small, sedge-peat bog at elev. $732 \mathrm{~m}$ in kettle hole in extensive recent glacial deposits. Coll. 1968 and subm. by J. H. Anderson.

\section{M-2219. Sample No. 373}

$2560 \pm 140$

610 B.C.

Dark gray organic material mixed with fine sand and some macroscopic plant remains. Depth, 160 to $183 \mathrm{~cm}$ in base of major peat sec. extending to surface.

\section{M-2220. Sample No. 276}

$6700 \pm 300$

Dark gray, very fine-grained organic material mixed with some clay. Compact organic-clay matrix contains few macroscopic plant remains including stems and gymnosperm seeds. Depth, 645 to $669 \mathrm{~cm}$.

\section{M-2221. August 22nd Bog, Canada}

$8000 \pm 350$

\section{B.C.}

Fine-grained, firm peat from August 22nd Bog (59 22' 10" N Lat, $133^{\circ} 24^{\prime} 08^{\prime \prime}$ W Long), British Columbia, Canada, from depth 323 to $346 \mathrm{~cm}$ at base of major peat sec. extending to surface. Sedge-sphagnum peat bog is ca. $91.5 \mathrm{~m} \mathrm{~N}$ of O'Donnel River Rd., $29 \mathrm{~km}$ airline SE of Atlin. Coll. 1968 and subm. by J. H. Anderson.

General Comment (J.H.A.): individually, dates enable calculation of sediment accumulation rates and the dating of vegetation changes, as inferred from pollen diagrams, at sites. Collectively, dates are basis of an absolute chronology for 9 major geobotanic or bioclimatic time zones established for Atlin region, from ca. 11,500 B.P. to present (Anderson, 1970).

\section{Kuhl Mastodon site series, Michigan}

Wood and slightly decomposed peat from Kuhl Mastodon site $\left(42^{\circ}\right.$ $15^{\prime} 24^{\prime \prime}$ N Lat, $84^{\circ} 57^{\prime} 30^{\prime \prime}$ W Long), T.2S, R.4E, Sec. 33, (SW?), NE, SE, Lima Twp., Washtenaw Co., Michigan. Site NW (outside) of Ft. Wayne Moraine of $\mathrm{E}$ edge of depression of unknown extent. Coll. 1969 by R. S. Rhodes; subm. by W. R. Farrand, Dept. Geol., Univ. of Michigan. 


\section{M-2435. Kuhl Mastodon site

Sample, KM-17-a, is slightly decomposed peat of unknown composition, from depth $43 \mathrm{~cm}$, will date close to cessation of deposition in basin but is hopefully below much contamination from modern rootlets. It will also be uppermost dated sample in quantitative pollen study.

\section{M-2436. Kuhl Mastodon site}

$4470 \pm 160$

(a) touching a mastodo rib, in horizon ca. $180 \mathrm{~cm}$ deep, will date assoc. mastodon remains and provide part of time framework for a quantitative pollen study.

General Comment (W.R.F.): considering these 2 dates and 2 others from same site (I-5080: 11,050 \pm 160 B.P. on organic debris at -200 $\mathrm{cm}$ in close assoc. with mastodon bones and I-5081: $9590 \pm 160$ B.P. on woody fragments at $-130 \mathrm{~cm}$ ), M-2435, I-5081, and I-5080 are probably in their correct stratigraphic sequence, but M-2436 is distinctly out of line. M-2436 dates a conifer log in vertical position (but not apparently rooted) next to a disarticulated rib of the mastodon. Both its position and reported age suggest that the log was either intrusive into bog long after death of mastodon or date is spurious.

\section{Akron Mastodon site series, Ohio}

Mastodon bone and wood from Akron Mastodon site $\left(41^{\circ} 10^{\prime} \mathrm{N}\right.$ Lat, $81^{\circ} 30^{\prime} \mathrm{W}$ Long), Akron, Summit Co., Ohio. Coll. 1966 by R. F. Keller and R. O. Kapp; subm. by R. O. Kapp, Dept. Biol., Alma College, Alma, Michigan.

\section{M-1970. Mastodon bone}

Remains discovered during excavation of building.

\section{M-1971. Wood}

Portion of trunk $15.2 \mathrm{~cm}$ diam., possibly spruce. Discovered during building excavation; should be approx. contemporaneous with mastodon. General Comment (J.B.G.): dates are reasonable for mastodon in this area.

\section{Upper Mississippi Valley and Great Lakes}

\section{Itasca Bison site series, Minnesota}

Wood, peat, and conifer cone fragments from Itasca Bison site $\left(47^{\circ}\right.$ 12' N Lat, 95 14' W Long), Minnesota (Shay, 1963, 1971) Coll. 1964 and subm. by C. T. Shay, Univ. of Minnesota.

\section{M-1725. Itasca Bison site}

Conifer cone fragments, Cat. No. 540-1483, (21 Picea glauca and 1 P. Mariana), from 8 to $9 \mathrm{~W}, 12.20$ to $12.55 \mathrm{~N}$ at depth 2.87 to $2.95 \mathrm{~m}$ in sandy marl at base of pollen, shell, and soil series. Cones are possible 
part of "trash" layer forming interface between till and marl. Basal pollen spectrum represents spruce dominance. Should date base of marl layer overlying till of ca. 11,000 B.c. plus, which date is based on stratigraphic position, basal pollen spectrum, and date at Bog D, $3.22 \mathrm{~km}$ SE of site, of 11,000 B.C. (Y-1418, R., 1969, v. 11, p. 576).

\section{M-1726. Itasca Bison site}

$7200 \pm 250$ 5250 в.C.

\section{Rerun- $7740 \pm 270$} 5790 B.c.

Wood fragments including bark, Cat. No. 540-1836 from $15.70 \mathrm{~W}$, $12.46 \mathrm{~N}$ at depth $2.20 \mathrm{~m}$ in coarse sand with shell. Assoc. with pollen and knife. Postdates deposition of scapula and predates knife. Age should be ca. 9000 B.P. based on assoc. pollen spectrum, in pine period, upper limit of which was dated $3.22 \mathrm{~km}$ away at Bog D at 8500 B.P. (Y-1419, R., 1969, v. 11, p. 576).

\section{M-1728. Itasca Bison site}

$1870 \pm 130$

Wood and twig fragments, Cat. No. 540-620, from 41.10 to 41.25 $\mathrm{N}, 1.50$ to $1.75 \mathrm{E}$ at depth 2.05 to $2.10 \mathrm{~m}$ in part of wood concentration above pebble and sandy marl layer and below ca. $1 \mathrm{~m}$ of sedge peat. Assoc. with concave base, side-notched projectile point and pollen. Should date deposition of projectile point and predate peat formation at 2000 to 4000 B.P. Pollen evidence indicates hiatus in depositional sequence up to $6000 \mathrm{yr}$. Most cultural material occurs below presumed hiatus and some bones above it may be redeposited. Peat development presumably began late here, maybe as late as 2000 B.P. Therefore, sample may not show age of projectile point.

\section{M-1729. Itasca Bison site}

$8580 \pm 300$

Wood, Cat. No. 540-1628, from 6.95 to $6.99 \mathrm{~W}, 18.56$ to $19.00 \mathrm{~N}$ at depth $2.61 \mathrm{~m}$ in sand directly under sandy marl. Assoc. with Bison bone and pollen. Should date wood concentration stratum below bone concentration and predate deposition of bone with est. age of 11,000 B.P. based on pollen spectrum assoc. with Bison tibia.

\section{M-1730. Itasca Bison site}

$7370 \pm 250$

Wood, Cat. No. 540-933, from $35.00 \mathrm{~N}, 9.47 \mathrm{~W}$ at depth $2.55 \mathrm{~m}$ in marl. Assoc. with Bison bones and pollen. Should date horizon near upper limit of marl in immediate area and is contemporaneous with and predates Bison bones, with age est. ca. 9000 to 10,000 B.P. based on assoc. pollen spectra at similar depth.

General Comment (C.T.S.): with exception of M-1728, dates are substantially later than expected. 
Voss site series, Ohio

Charcoal, midden refuse, and vegetal material from Voss site $\left(39^{\circ}\right.$ 53' 02" N Lat, $83^{\circ} 12^{\prime} 48^{\prime \prime}$ W Long), Pleasant Twp., Franklin Co., Ohio. Cole-type site; mound erected over ceremonial center and burials at edge of center. Ceremonial house structure (nearly square, round cornered) $30.5 \mathrm{~m} \mathrm{~N}$ of ceremonial center (Baby, Potter, and Mays, 1966). Coll. 1966 and subm. by R. S. Baby, Ohio State Mus., Columbus, Ohio.

M-1870. Feature II

Refuse pit.

M-1871. Feature II

Refuse pit.

M-1872. Feature III

Refuse pit.

M-1873. Feature IV

Refuse pit.

M-1875. Feature VII

Refuse pit.

M-1876. Feature VIII

Refuse pit.

M-1877. Feature IX

Refuse pit and foetal burial.

M-1879. Feature XIV

Refuse pit.

M-1881. Feature XIX

Refuse pit assoc. with House II.

M-1882. Feature XX

Refuse pit assoc. with House II.

M-1883. Sq. 220 L 10

Midden area, Feature XI.
$720 \pm 100$

A.D. 1230

$550 \pm 100$

A.D. 1400

$575 \pm 100$

A.D. 1375

A.D. 1170

$780 \pm 110$

$1030 \pm 120$

A.D. 920

$450 \pm 100$

A.D. 1500

$520 \pm 100$

A.D. 1430

$540 \pm 100$

A.D. 1410

A.D. 1120

$830 \pm 100$

A.D. 1070

$880 \pm 100$

$470 \pm 100$

A.D. 1480 


\section{M-1884. Sq. 190 L 12}

A.D. 1480

Midden area, Feature XVIII, House I, small sample.

General Comment (J.B.G.): dates are later than expected by excavators and show unexpected time range. Presence of strap handles and guilloche decoration, however, suggests that at least part of occupation is between A.D. 1200 and 1400 .

\section{M-2010. Oliver Farm site, Indiana}

$890 \pm 100$

Carbonized wood from Oliver Farm site $\left(39^{\circ} 54^{\prime} 30^{\prime \prime} \mathrm{N}\right.$ Lat, $86^{\circ}$ $05^{\prime} 30^{\prime \prime}$ W Long), NE 1/4, NE 1/4 Sec. 20, Twp. 17N, Range $4 \mathrm{E}$, Marion Co., Indiana. Sample from Feature 22, basin-shaped pit beneath more recent alluvial deposits. Pit contained Late Woodland-Fort Ancient pottery, mammal and fish bone. Should date Late Woodland occupation, probably Late Prehistoric to early Historic. Sample placed in Oliver focus (Griffin, 1946) and is characterized by apparent Fort Ancient influence. Coll. 1967 and subm. by J. H. Kellar, G. A. Black Lab. Archaeol., Indiana Univ., Bloomington. Comment (J.H.K.): date does not confirm supposed Late Prehistoric or Early Historic occupation. But, with no definitive study of samples and with possibility of some temporal depth present at sites used to define the focus, date might prove correct for some local chronology.

\section{M-2076. Boyce Village site, Missouri}

$1020 \pm 120$

Partially burned acorns from Boyce Village site $\left(38^{\circ} 10^{\prime} \mathrm{N}\right.$ Lat, $91^{\circ}$ $30^{\prime}$ W Long), Jefferson Co., Missouri. Sample from corner of Feature 2. Coll. late 1930's by R. McC. Adams; subm. by J. B. Griffin. Comment (J.B.G.): Middle Mississippian site with a considerable amount of claytempered cord-marked pottery and Old Village vessels (Adams, 1941; Adams, 1949).

\section{Long Village site series, Missouri}

Charred wood and corn from Long Village site $\left(38^{\circ} 15^{\prime} \mathrm{N}\right.$ Lat, $91^{\circ}$ $15^{\prime}$ W Long), Jefferson Co., Missouri. Middle Mississippian site (Adams, 1949). Coll late 1930's by R. McC. Adams; subm. by J. B. Griffin.

\section{M-2077. Long Village site}

Charred wood, probably red oak, from F-9, M-66, Sq. 8L1.

\section{M-2087. Long Village site}

Burned corn from F-9, M-66, Sq. 8L1.

General Comment (J.B.G.): dates do not apply to substantial Old Village occupation; charred corn and charred oak have essentially same date. 


\section{M-2110 and M-2111. Thurman site, Missouri}

Small fragments of charcoal from Thurman site (23 HE 151) $\left(38^{\circ}\right.$ $16^{\prime} 12^{\prime \prime} \mathrm{N}$ Lat, $93^{\circ} 35^{\prime} 25^{\prime \prime} \mathrm{W}$ Long), Henry Co., Missouri. Material from hearth, Feature 62, in NE 1/4, Unit $60 \mathrm{SW} 5$, Level 4 below cultural zone. Assoc. with lithic material, probably Late Archaic component. Samples combined; M-2110 from $58.5 \mathrm{~cm}$ below datum, and M-2111 from 57.8 cm below datum. Coll. 1967 by C. R. Falk; subm. by W. R. Wood, Univ. of Missouri, Columbia, Missouri. Comment (C.R.F.): date is consistent with both stratigraphic evidence and $\mathrm{C}^{14}$ dates from nearby sites (M-1929, $2680 \pm 150$ B.P., R., 1968 , v. 10, p. 86, and GXO-749), and appears to document Late Archaic occupation in W margins of Ozark Highlands, Missouri.

\section{Collins site series, Missouri}

Charcoal from Collins site (23 MN 223) (39 $30^{\prime} \mathrm{N}$ Lat, $91^{\circ} 30^{\prime}$ W Long), Monroe Co., Missouri. Coll. 1968 by Alan Osborn; subm. by W. E. Klippel, Illinois State Mus., Springfield, Illinois.

\section{M-2142. Feature 2}

$2610 \pm 200$

From basin-shaped pit, 45.7 to $71.1 \mathrm{~cm}$ below site surface. Pit contained charred walnut hulls, bone, 2 Woodland points, burned clay, 2 small sherds, many chert flakes, burned limestone, chert hammer stones, retouched flakes, bi-pitted mano, and some roots of modern vegetation.

\section{M-2143. Feature 9}

$2520 \pm 150$

From basin-shaped pit, 35.6 to $60.9 \mathrm{~cm}$ below site surface. Pit contained few charred nut hulls, some bone, many flakes, burned clay, 2 proximal projectile point fragments, misc. stone, and roots of modern vegetation.

General Comment (W.E.K.): samples date a late Archaic/Early Woodland transition occupation in Missouri's Prairie Peninsula. These are the earliest dates for a ceramic-bearing assemblage in N Missouri. Ciontents of site, indicate dates are fairly reliable.

\section{Twenhafel site series, Illinois}

Charcoal from Twenhafel site $\left(37^{\circ} 40^{\prime} \mathrm{N}\right.$ Lat, $89^{\circ} 31^{\prime} \mathrm{W}$ Long), Jackson Co., Illinois. Near Gorham and Fountain Bluff. Coll. 1958 by J. R. Caldwell; subm. by Thorne Deuel, Illinois State Mus., Springfield, Illinois.

\section{M-1190. Twenhafel}

$$
1150 \pm 150
$$

From fill of abandoned storage pit containing Raymond sherds exclusively. Date should fall within Raymond period of Late Woodland period of S Illinois. 


\section{M-1191. Twenhafel}

$550 \pm 100$

From burned timbers of a house (Feature 18) containing Mississippian pottery.

\section{M-1192. Emmons site, Illinois}

$\mathbf{5 2 0} \pm \mathbf{2 0 0}$

Charcoal from Emmons site (40 $11^{\prime} \mathrm{N}$ Lat, $90^{\circ} 13^{\prime} \mathrm{W}$ Long), Fulton Co., Illinois. From burned timber of a Mississippian house. Pottery on house floor was Mississippian Plain and Cordmarked; the latter resembled Cahokia Cordmarked but with interior red slips. Coll. 1960 by J. R. Caldwell; subm. by Thorne Deuel.

\section{Dickson Mound series, Illinois}

Charcoal from Dickson Mounds $\left(40^{\circ} 20^{\prime} \mathrm{N}\right.$ Lat, $90^{\circ} 10^{\prime} \mathrm{W}$ Long), Fulton Co., Illinois. Pre-Spoon River Mississippian occupation at the Eveland Tract, Dickson Mounds. Coll. 1959 and 1960 by J. R. Caldwell; subm. by Thorne Deuel.

\section{M-1193. Dickson Mounds}

$$
680 \pm 150
$$

From burned roof timbers of an earthlodge-like structure, House 2.

\section{M-1194. Dickson Mounds}

\section{A.D. 1300}

$$
650 \pm 200
$$

From a burned timber of House 6 which had a cruciform ground plan.

\section{M-1195. Meyer (Bluff) Cave, Illinois \\ $1040 \pm 150$}

Charcoal from Meyer (Bluff) Cave zoologic deposit, NW 1/4, Sec. 6, T.2S, R.10W, New Hanover Twp., Monroe Co., Illinois. From cave zoologic deposit layer .915 to $1.22 \mathrm{~m}$ down. Nearby in same level are bones of striped skunk, spotted skunk, and porcupine, all extinct in Illinois. Coll. 1960 by Paul Parmalee; subm. by Thomas Deuel.

General Comment (T.D.): Raymond is S Illinois Late Woodland focus and differs from analogous focus in Fulton Co. The dates for Late Woodland at Bluff Cave and Mississippian "Old Village" at Eveland do seem rather close together, but sites are $161 \mathrm{kms}$ apart. Hopewellian maintained its characteristic artifacts longer in S Illinois than farther $\mathrm{N}$, consequently Late Woodland appears later in S Illinois.

Middle Mississippian culture seems to have flourished at Cahokia and vicinity from 10 th century or earlier to ca. 1500 or somewhat later. Dates for sites of that culture lie within that range.

Because 5 or possibly 6 foci of Late Woodland are strung from the $\mathrm{S}$ to $\mathrm{N}$ boundaries of Illinois and all show incipient Mississippi traits, it seems that Mississippian culture in Illinois developed out of Late Woodland which in turn had replaced Hopewellian. 


\section{M-2045. New Castle site, Indiana}

Charcoal from New Castle site (40 $47^{\prime} 03^{\prime \prime} \mathrm{N}$ Lat, $85^{\circ} 21^{\prime} \mathrm{W}$ Long), T.17N, R.10E, SW 1/4, NE 1/4, Sec. 2, Henry Co., Indiana. Sample from 8F9-11, Pit N1-W7, 0 to $40.7 \mathrm{~cm} \mathrm{~N}, 35.6$ to $50.8 \mathrm{~cm} \mathrm{E}, 22.8 \mathrm{~cm}$ deep, Woodland site (Swartz, 1966; Lilly, 1963; Redding, 1892; Strickler and Wilson, 1967). Coll. 1965 by Walter Koch; subm. by B. K. Swartz. Comment (B.K.S.): date is somewhat later than A.D. $10 \pm 140$ obtained from previous sample deeper in earthwork, M-1852 (R., 1970, v. 12, p. 163). It seems to be from a later component, probably the one of the intrusive infant burial. Sample was stored in paper and may be slightly contaminated.

\section{Malone Site series, Michigan}

Charcoal from Malone site (43 $15^{\prime} \mathrm{N}$ Lat, $83^{\circ} 15^{\prime} \mathrm{W}$ Long), Saginaw Co., Michigan, $153 \mathrm{~m} \mathrm{~S}$ of $\mathrm{N}$ edge of ridge above flood plain 183 m W of Flint R. Coll. 1967 by Bernard Spence; subm. by J. E. Fitting, Case Western Reserve Univ., Cleveland, Ohio.

\section{M-2122. Feature 9}

Upper element: assoc. with shell-tempered Oneota rim, late Saginaw Wayne ware with narrow neck and many small castellations, a sherd of Parker Festooned, and carved bone antler. Should date Mississippian influenced Woodland in Saginaw Valley: ca. A.D. 1300 to 1500. Comment (J.E.F.): dates distinctive Mississippian occupation at Malone site and is very satisfactory. Occupation is known from rare surface colls., but Malone is lst site where it was isolated.

\section{M-2123. Feature 10}

A.D. 1100

$850 \pm 110$

Lower element: assoc. with large, globular Wayne ware vessel, 2 Pickering (?) rim sherds, and drilled shell fragments. Should date Saginaw Valley Late Woodland similar to Bussinger site or slightly later: ca. A.D. 1100 to 1400. Comment (J.E.F.): dates late Woodland feature, is satisfactory, and is in correct stratigraphic placement in relationship to M-2122, as well as consistent with other Saginaw Valley Late Woodland dates from Schultz and Bussinger sites (R., 1968, v. 10, p. 74, 77, and 78).

\section{M-2218. Van Nuys site, Indiana}

$120 \pm 100$

Charcoal from Van Nuys site (12 Hn 25) (39 $59^{\circ} 30^{\prime \prime} \mathrm{N}$ Lat, $85^{\circ}$ 22' 00" W Long), T.17N, R.10E, NW 1/4, Sec. 2, Henry Twp., Henry Co., Indiana, from SE corner of pit S16, W1, $8.25 \mathrm{~cm}$ deep, assoc. with firepit. Pottery is Late Woodland. Coll. 1968 by Ben Morris; subm. by B. K. Swartz, Jr., Ball State Univ., Muncie, Indiana. Comment (B.K.S.): sample was recovered from an undisturbed area, but not in direct assoc. with any pottery, the features of which would not rule out possible 
proto-historic late Woodland occupation at the Van Nuys site (Swartz, 1970, p. 15).

\section{M-2223. Peisker site, Illinois}

$1860 \pm 140$

Wood charcoal from Peisker site $\left(39^{\circ} 05^{\prime} 26^{\prime \prime} \mathrm{N}\right.$ Lat, $90^{\circ} 35^{\prime} 43^{\prime \prime}$

W Long), Calhoun Co., Illinois, from a Havana-Hopewell habitation site underlying a Hopewell burial mound. Sample from pit intruded into fossil river beach underlying Mound 3 prior to mound construction. Feature 5, Submound 3. Assoc. with Havana- and Hopewell-ware sherds. Should date Havana-Hopewell phase in Lower Illinois Valley. Coll. 1968 and subm. by Stuart Struever, Northwestern Univ., Evanston, Illinois. Comment (S.S.): pottery is "early Hopewell" and date seems appropriate.

\section{Macoupin site series, Illinois}

Wood charcoal and charred nuts from Macoupin site $\left(39^{\circ} 10^{\prime} \mathrm{N}\right.$ Lat, $90^{\circ} 34^{\prime} 30^{\prime \prime}$ W Long), Jersey Co., Illinois. Coll. 1968 by F. Rackerby and Stuart Struever; subm. by Stuart Struever.

\section{M-2225. Sample 6}

$2020 \pm 200$ 70 B.c.

Small fragments of wood charcoal and possibly charred nutshells from redeposited hearth assoc. exclusively with Havana-ware sherds. Not a good run.

\section{M-2226. Sample 9}

$2410 \pm 210$

Consolidated wood charcoal and possibly nutshell from areas within fill of pit feature, No. 31. Charcoal is probably redeposited general midden.

\section{M-2229. Sample 109}

$1950 \pm 200$

O B.C./A.D.

Charcoal from pit containing exclusively Havana-Hopewell pottery; no Pike or Baehr pottery. Pit, Feature 127, contained limestone slab and restorable vessel. Small sample.

\section{M-2243. Sample 63}

$1900 \pm 140$

Wood charcoal from charcoal concentration in redeposited hearth excavated in upper level of large refuse-storage pit, Feature 173. Charcoal from a single fire appears to be represented here. Sample from pit containing exclusively Havana-ware and Hopewell-ware sherds.

\section{M-2244. Sample 97}

$1500 \pm 130$

Redeposited charcoal in pit fill, Feature 44b. Pit contained 8 Havana-ware and 2 Crab Orchard Fabric-Impressed sherds only. 


\section{M-2245. Sample 101}

Redeposited hearth residue in pit feature, No. 215. Six Havanaware sherds were recovered from this feature.

General Comment (S.S.): all 6 dates were from context containing Havana-ware and Hopewell-ware pottery only and should pertain to Havana-Hopewell phase (i.e., "early Hopewell") in the lower Illinois Valley. M-2225, M-2229, M-2243, and M-2245 fall within 100 B.c. to A.D. 200 range expected for Havana-Hopewell. M-2226 is much too early and probably represents redeposited charcoal assoc. with a preceding. Black Sand phase site at Macoupin; date is appropriate for Black Sand. M-2244 is too late for Havana-Hopewell, but falls within range of later Pike-Hopewell phase. This charcoal may be assoc. with the Pike-Hopewell occupation at Macoupin.

\section{Old Clarksville site series, Indiana}

Charcoal from Old Clarksville site $\left(38^{\circ} 17^{\prime} 20^{\prime \prime} \mathrm{N}\right.$ Lat, $85^{\circ} 46^{\prime} 00^{\prime \prime}$ W Long), Clark Co., Indiana. Sample from midden deposit; should date Archaic occupation of Indian Knoll "type". Coll. 1969 and subm. by D. E. Janzen, Beloit College, Beloit, Wisconsin.

\section{M-2307. Old Clarksville site}

$4180 \pm 180$

Unit C, 38.1 to $45.7 \mathrm{~cm}$ below datum.

\section{M-2308. Old Clarksville site}

$60 \pm 18$

Unit F, 60.9 to $68.5 \mathrm{~cm}$ below datum.

\section{M-2309. Old Clarksville site}

$4460 \pm 180$

Unit D, 60.9 to $68.5 \mathrm{~cm}$ below datum. 2510 B.c.

General Comment (D.E.J.): samples date Indian Knoll type component at the Falls of the Ohio R.

\section{M-2342. Hopewell site, Ohio}

$1620 \pm 140$ A.D. 330

Wood charcoal, ash, id. by Suzanne Harris, from Mound 17, Hopewell site, Ross Co., Ohio. Possibly from "charred oak" of Moorehead or charcoal on mound floor. Assoc. with 3000 sheets of mica, 200 lbs. of galena, and fossil sharks teeth. From Field Mus. colln. Coll. 1891 by W. K. Moorehead; subm. by J. B. Griffin with permission of Donald Collier, Field Mus. of Nat. History, Chicago. Comment (J.B.G.): somewhat later than expected.

\section{M-1784. Cahokia Mound 51, Illinois}

$910 \pm 110$

Burned twigs and grass (R-14) from Cahokia Mound 51 (38 $39^{\circ}$ $48^{\prime \prime} \mathrm{N}$ Lat, 90 $13^{\circ} 33^{\prime \prime}$ W Long) St. Clair Co., Illinois. Mound across from old Ramey house, SE corner of Monks Mound at corner of US 40 and Catherine St., 20.3 to $25.4 \mathrm{~cm}$ below top of water laid (very hard 
packed) silty sand (heavy rust line). Water laid material found below base of mound fill. Assoc. pottery, composed of much shell; would suggest mound was built later in sequence of mounds. Coll. and subm. by James Porter, P.O. Box 276, Marshall, Wisconsin.

\section{M-1785. Bischoff site, Illinois}

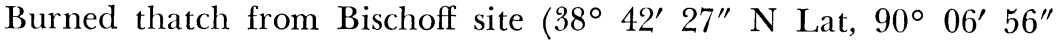
W Long), SE $1 / 4$, SE $1 / 4$ Sec. 17, Twp. 3 N, Range 9 W, Madison Co., Illinois, from $35 \mathrm{~m} \mathrm{~S}$ and $10.7 \mathrm{~m} \mathrm{E}$ of construction stake $2+24.74$ at $1 \mathrm{~m}$ depth below surface of 420 to 422 contour ridge. Assoc. with Mississippian and Cahokia Cordmarked pottery. Coll. 1965 and subm. by James Porter. Comment (J.B.G.): excellent date for this assemblage.

\section{Bowen site series, Indiana}

Charred wood from Bowen site $\left(39^{\circ} 53^{\prime} 45^{\prime \prime} \mathrm{N}\right.$ Lat, $86^{\circ} 07^{\prime} 10^{\prime \prime} \mathrm{W}$ Long), Marion Co., Indiana. Coll. 1961 and 1963 by J. C. Householder; subm. by J. H. Kellar and J. T. Dorsey, Glenn A. Black Lab. Archaeol., Indiana Univ., Bloomington, Indiana.

\section{M-2421. Bowen site}

$1370 \pm 130$

Feature 46, a circular refuse pit $1.37 \mathrm{~m}$ diam.; floor lined with heat-cracked rock and large pieces of charred wood. Entire bottom showed heavy burning in form of ash and reddened soil. Sample from charred $\log 1.09 \mathrm{~m}$ below surface and well within burned area. Fort Ancient and Late Woodland pottery and considerable corn in pit.

\section{M-2422. Bowen site}

\section{A.D. 1210}

$740 \pm 110$

Feature 88. Large rectangular refuse pit 2.14 by $1.83 \mathrm{~m}$, from .49 to $.61 \mathrm{~m}$ level under dog burial but still $.18 \mathrm{~m}$ above floor. Fort Ancient and Late Woodland pottery mixed in pit.

General Comment (J.B.G.): M-2421 is too early for assoc. cultural material which should be closer in time to date on M-2422.

\section{M-2424. Yankeetown site, Indiana}

$2840 \pm 250$

890 B.C.

Carbonized plant material from Yankeetown site (12 W 1) (37० $54^{\prime} 20^{\prime \prime} \mathrm{N}$ Lat, $87^{\circ} 18^{\prime} 45^{\prime \prime} \mathrm{W}$ Long), Anderson Twp., Warrick Co., Indiana. Sample from Feature 7, a circular pit with rounded bottom occurring in alluvial deposits at depth 3.37 to $3.54 \mathrm{~m}$ below ground surface. Pit contained numerous fragments of hickory and walnut as well as flint chips, 2 pieces of sandstone, and 1 flint nodule. Date should approximate M-2009: $2740 \pm 150$ B.P. (R., 1970, v. 12, p. 170). Coll. 1968 by Kent Vickery; subm. by J. H. Kellar. Comment (J.B.G.): date supports age assessment on M-2009 for this Early Woodland horizon at Yankeetown site. 


\section{Mounds State Park series, Indiana}

Carbonized plant material from Mounds State Park (12 M 2) $\left(40^{\circ}\right.$ $06^{\prime} \mathrm{N}$ Lat, $85^{\circ} 37^{\prime} 30^{\prime \prime} \mathrm{W}$ Long), Union Twp., Madison Co., Indiana, from large circle ca. $91.5 \mathrm{~m}$ diam. defined by a deep trench, removed earth cast outside with an entrance to the SW. A small mound is in approx. center, consisting of 2 primary structures, the earlier being 3 superimposed baked clay platforms. The secondary mantle contained 4 burials, 2 of which were in a $\log$ tomb. Assoc. artifacts: a plain platform pipe, bone bear effigy canines, and ceramics seemingly related to the Newcastle series. Coll. 1969 by Kent Vickery; subm. by J. H. Kellar, Dept. Anthropol., Indiana Univ., Bloomington, Indiana.

\section{M-2428. Post Hole 2}

$1720 \pm 130$

Protruding into primary platform in small mound in approx. center of "Great Mound".

\section{M-2429. Post Hole 3}

$2010 \pm 140$

Protruding into primary platform in small mound in approx. center of "Great Mound."

General Comment (J.B.G.): dates are satisfactory for E central Indiana middle Woodland complex.

\section{Lower Mississippi Valley and Southeast U.S.}

\section{M-2075. Spiro site, Oklahoma}

$840 \pm 110$

Bark (Juniperus virginiana) from Spiro site $\left(35^{\circ} 18^{\prime} 45^{\prime \prime} \mathrm{N}\right.$ Lat, $94^{\circ}$ $30^{\prime} 00^{\prime \prime}$ W Long), Le Flore Co., Oklahoma, from Craig Mound, combining A-20, Layers 2 and 3, and B167-4, from adjacent layers of cedar bark that cover group burials in a small primary mound in 3rd mound unit of Craig (Brown, 1966). Sample lies stratigraphically above burial (B-177) with vessels of French Fork Incised, Coles Creek Incised, and Le Flore Plain assoc. with a "bugstone" quartz crystal effigy atlatl weight. Burial is one of Orr's (1952) principal Evans Focus graves. Coll. 1937 by F. E. Clements; subm. by J. A. Brown, Dept. Anthropol., Michigan State Univ., East Lansing. Comment (J.A.B.): stratigraphically equivalent sample was assayed as O-2283 (Brown, 1967) dated $500 \pm 100$ в.P. Latter determination was thought too young and, although present $\mathrm{C}^{14}$ date is older and more consistent with other Spiro dates, it still is probably too young.

\section{M-2149. Pine Harbor site, Georgia}

$810 \pm 110$

Charred wood from Pine Harbor site (9 McI 64) (31' $33^{\prime}$ N Lat, $81^{\circ} 22^{\prime}$ W Long), McIntosh Co., Georgia. From base of short (probably one season) occupation shell heap. Late, immediately pre-Spanish Lamar occupation. Coll. 1966 by Trawick Ward; subm. by L. H. Larson, Eastern Kentucky Univ., Richmond, Ky. Comment (L.H.L.): sample 
dated too early, even if end of its time range is considered. Typologically, the materials appear to belong to the period immediately preceding the arrival of the Spanish on the Georgia coast in the latter half of the 16th century.

\section{M-2187. Schafner Mound I site, Illinois}

$1730 \pm 140$

Charred human bone from Schafner Mound I site $\left(39^{\circ} 31^{\prime} 03^{\prime \prime} \mathrm{N}\right.$ Lat, $90^{\circ} 59^{\prime} 37^{\prime \prime} \mathrm{W}$ Long), Pike Co., Illinois. Hopewell burial mound containing a $\log$ tomb; Havana vessels assoc. with bundle burials, 5 vessels covered with red ochre. Coll. and subm. by Gregory Perino, Thomas Gilcrease Inst. Am. History and Art, Tulsa, Oklahoma. Comment (G.P.): date verifies continued manufacture of Havana ware at this late date.

\section{Dumond site series, Arkansas}

Charcoal from Dumond site (3 AR 40) (34 $16^{\prime} \mathrm{N}$ Lat, 91 $11^{\circ} \mathrm{W}$ Long), Arkansas Co., Arkansas. Samples from mound-buried houses at extensive multicomponent site. Remains under Mounds 4 and 6 are of round Baytown houses with 4-center-support-post construction and large central basin firepits; major assoc. pottery types Baytown Plain and Mulberry Creek cord marked, minor Evansville Punctated, Larto Red Filmed, and Indian Bay Stamped. Remains under Mound 59 are of a rectilinear Mississippi house with central hearth and no interior supports; major assoc. pottery type Neeley's Ferry Plain, minor Old Town Red and Parkin Punctated. Earlier report of site describes different house construction at an intermediate component (Scholtz, 1968). Coll. 1968 by J. A. Scholtz; subm. by C. R. McGimsey, Ark. Archaeol. Survey,
Fayetteville, Arkansas.

\section{M-2139. Mound 6}

$990 \pm 150$

Sample 68-285-333. Central firepit of Baytown house, 200 to 227 $\mathrm{cm}$ below datum.

\section{M-2140. Mound 6}

$790 \pm 110$

Sample 68-285-241. Wall posthole of Baytown house, 180 to 195 $\mathrm{cm}$ below datum.

\section{M-2141. Mound 4}

Sample 68-285-180. Central firepit of Baytown house.

\section{M-2144. Mound 59}

\section{A.D. 1520}

$430 \pm 100$

Sample 68-285-S61. Central hearth of Mississippi house, $220 \mathrm{~cm}$ below datum.

General Comment (C.R.McG).: dates are consistent with assoc. materials and may be considered good. Samples M-2139-2141 should be nearly identical dates and easily overlap within the $1 \sigma$ range. House under 
Mound 6 was rebuilt at least once, but central firepit was used through all periods of house suggesting an actual 200-yr difference between any of the walls and firepit. These 3 samples average A.D. 1090, close to a terminal date for Baytown in $\mathrm{E}$ Arkansas. The Mississippi house of M-2144 is adjacent to a large flat-topped pyramidal temple mound and is probably contemporaneous with it.

\section{M-2154. Poverty Point site, Louisiana}

Charred cane from Poverty Point site (16 wC 2) (32 $38^{\prime} 10^{\prime \prime} \mathrm{N}$ Lat, $91^{\circ} 24^{\prime} 20^{\prime \prime}$ W Long), West Carroll Parish, Louisiana, N sec., Ridge 2, at junction of ridge and bank of Bayou Macon. Sample from mass of charred cane in shallow pit immediately subadjacent to midden exposed to caving and protected under root system of large tree, ca. $2.44 \mathrm{~m}$ from surface, in lowest occupation level. Beneath tree was level length of midden, with 3.66 to $7.32 \mathrm{~m}$ unburned streaks in lower part, immediately above and extending laterally on each side of sample pit. Suggests burning of house and partial firing of pit material. Below midden and around pit was sterile, undisturbed Arkansas white clay-sand. Assoc. with Poverty Point clay objects, cylindrical grooved and cross-grooved, with other occupational debris, but no sherds. Coll. 1968 by Mitchell Hillman; subm. by C. H. Webb, The Childrens Clinic, Shreveport, Louisiana. Comment (C.H.W.): sample is part of same material from which Tx-680, $3000 \pm 90$ B.P. (R., 1970 , v. 12, p. 636-637), was derived. The two dates are consistent within 1 o range and agree reasonably well with M-403: $2850 \pm 250$ в.P. (Science, 1958, v. 127, p. 1101); L-195: $2860 \pm 90$ (Science, 1956, v. 124, p. 163); O-66: $3150 \pm 120$ (Science, 1957, v. 125, p. 149) and several others from the site (Ford and Webb, 1956, p. 121-122). Present date and the one from Texas Lab. suggest construction of geometric ridges at Poverty Point began after 1000 to 900 B.c. Recent dates from Teoc Creek site (M-2393-95; M-2412-17, R., this issue) in Yazoo Basin of Mississippi established Poverty Point cultural occupation between 1700 B.c. and 1070 B.c. at this site and suggest that Poverty Point culture may have been established earlier along ancestral Mississippi R. than along ancestral Arkansas at Poverty Point site.

\section{Yokem Mounds site series, Illinois}

Charcoal and charred human bone from Yokem Mounds site $\left(39^{\circ}\right.$ $29^{\prime} 38^{\prime \prime} \mathrm{N}$ Lat, $90^{\circ} 56^{\prime} 16^{\prime \prime} \mathrm{W}$ Long), Pike Co., Illinois. Coll. and subm. by Gregory Perino.

\section{M-2188. Yokem Mounds 6 and 7}

$1040 \pm 120$

Charcoal from stone-lined subfloor tomb between Yokem Mounds 6 and 7.

M-2189. Yokem Mound 7

$1080 \pm 120$ A.D. 870

Charred human bone, fragment right femur and fragment innomi- 
nate bone of male, id. by C. L. Brace, Univ. of Michigan, from Feature A, Tomb A, Late Woodland.

\section{M-2190. Yokem Mound 8}

$$
1080 \pm 120
$$
Late Woodland.

\section{M-2191. Yokem Mound 9}

$1180 \pm 120$

Charred human bone, fragments of femur and skull, id. by C. L. Brace, from Feature A, Tomb A of mound.

General Comment (G.P.): tombs were constructed of limestone slabs. Pottery style is Late Woodland defined by 4 castilations on rim in "Maple Mills" style but these are earlier. Arrow points were sidenotched and made on flakes; dart points were small, usually fully flaked and also side-notched. Pipes were like some from Effigy Mound culture in Wisconsin. Average of dates shown should indicate latest period when Late Woodland people were making stone crypts in Illinois although at least 1 burned log structure was found in line with 2 stone structures in Mound 6. According to technologic progress noted for these people, M-2191 (A.D. 770) should be a mean date for existence of group.

\section{M-2256. McCarter Mound, Mississippi}

$1610 \pm 140$

Charcoal from McCarter Mound (ca. $34^{\circ} 20^{\prime} \mathrm{N}$ Lat, $90^{\circ} 54^{\prime} \mathrm{W}$ Long), Batesville, Panola Co., Mississippi, from balk 95 to $100,91.5 \mathrm{~cm}$ deep from 100 in mound, Stage 2, down from center. Twin Lakes phase of Hopewellian period. Purpose is to date appearance of conjoined tubes in Lower Mississippi Valley. Coll. and subm. by Glenn Johnson, Delano, Tennessee. Comment (G.J.): charcoal from Stage 2 construction which postdates copper conjoined tube and Crowder and Twin Lakes bowls. Date rules out possibility that Twin Lakes and Crowder Punctate pottery (from Stage 1) are later than $1610 \pm 140$ B.P. and supports an earlier date. Charcoal came from Stage 2, separated from Stage 1 by a humus layer, 7.62 to $12.7 \mathrm{~cm}$ thick, suggesting a considerable time lapse between Stage 1 and Stage 2 construction.

\section{Saint Albans site series, West Virginia}

Charcoal from St. Albans site (46 Ka 27) $\left(38^{\circ} 23^{\prime} \mathrm{N}\right.$ Lat, $81^{\circ} 48^{\prime}$ W Long), Kanawha Co., West Virginia. Coll. 1968 and subm. by Bettye Broyles, West Virginia Geol. Survey.

M-2288. St. Albans site

Charcoal, Cat. No. 135, from Zone 24.

M-2289. St. Albans site

Charcoal, Cat. No. 196, from Zone 16. $\mathbf{8 4 7 0} \pm 300$

6520 B.C.

$8800 \pm 320$

6850 в.c. 
M-2291. St. Albans site

Charcoal, Cat. No. 198, from Zone 20. Assoc. with small Kirk projectile point within zone. Yale date is 6980 в.c. \pm 160 (Y-1538, R., 1969, v. 11, p. 616).

M-2292. St. Albans site

$8240 \pm 300$

Charcoal Cat. No. 134, from Zone 12. Assoc. with St. Albans A projectile point within zone. Earlier Michigan date: 6880 в.C. \pm 700 (M-1821, R., 1968, v. 10, p. 96).

M-2293. St. Albans site

Charcoal, Cat. No. 133, from Zone 11, 75 R, 25, Feature 22. Assoc. with St. Albans B projectile point within zone. Earlier Michigan date: 6870 в.C. \pm 500 (M-1820, R., 1968, v. 10, p. 96). Small sample.

Charcoal, Cat. No. 204, from Zone 18. Assoc. with large Kirk cornernotched projectile point.

\section{M-2295. St. Albans site}

$8560 \pm 600$

Charcoal, Cat. No. 203, from Zone 19A or 20, circular hearth. Assoc. with large Kirk corner-notched projectile point.

General Comment (J.B.G.): dates should be compared with earlier Michigan and Yale age assessments (Broyles, 1971).

\section{Northeastern U.S.}

\section{Antonio site series, Pennsylvania}

Charcoal from Antonio site ( $41^{\circ} 59^{\prime} \mathrm{N}$ Lat, $77^{\circ} 16^{\prime} \mathrm{W}$ Long), Tioga Co., Pennsylvania. Possibly Early Woodland assoc. Coll. 1967 and subm. by J. W. Gruber, College of Liberal Arts, Temple Univ., Philadelphia, $\mathrm{Pa}$.

\section{M-2124. Sample 67-C1}

$$
800 \pm 110
$$

\section{A.D. 1150}

Feature $76, .885 \mathrm{~m}$ diam., $.794 \mathrm{~m}$ deep from interface, $1.02 \mathrm{~m}$ from stake $0+50$ L220. Charcoal in feature assoc. with bone and rim sherds.

\section{M-2125. Sample 67-C2}

$$
1160 \pm 120
$$

Feature 48, large discolored area $4.58 \mathrm{~m}$ diam. Charcoal throughout assoc. with sherds and flint artifacts including 2 points.

\section{M-2126. Sample 67-C3}

$$
1260 \pm 120
$$

Feature 64 . Bone, flint chips, and pottery sherds assoc. with charcoal. Lower half of feature. 
M-2127. Sample 67-C4

Feature $48 \mathrm{~A}$ intrusive in Feature 48. Charcoal assoc. with pottery and 1 point.

M-2128. Sample 67-C5

$$
2570 \pm 160
$$

620 B.C.

Feature 31, fire pit. Sample from beneath fire-cracked rocks in feature $.489 \mathrm{~m}$ deep from interface and $.326 \mathrm{~m}$ deep from top of stake $0+20$ L110.

General Comment (J.B.G.): dates suggest at least 2 occupations on site.

\section{St. Croix Island series, Maine}

Shell (Mya arenaria Linné) Gaper or soft shell clam, id. by Henry van der Schalie, Mollusc div., Mus. Zool., Univ. of Michigan, from St. Croix I., Maine. Coll. and subm. by J. W. Gruber, Temple Univ., Philadelphia.

M-2409. St. Croix Island

Sample STC-69-5, 50-18.

M-2410. St. Croix Island

Sample STC-69-5, 50-19.

M-2411. St. Croix Island

Sample STC-69-5, 50-20.

$\mathbf{0} \pm 100$

A.D. 1950

A.D. 1770

$$
180 \pm 100
$$

$150 \pm 100$

General Comment (J.B.G.): shell apparently assoc. with French occupation.

\section{Great Plains and Western U.S.}

\section{M-1420. Arp site, South Dakota}

$1140 \pm 120$

Charcoal from Arp site (39 BR 101) $\left(43^{\circ} 35^{\prime} \mathrm{N}\right.$ Lat, 99 $20^{\prime} \mathrm{W}$ Long), Brule Co., South Dakota. Sample from Excavation Unit 3, Feature 4, small fire pit in Level 4, at depth $104.3 \mathrm{~cm}$ from surface. Corn cobs and cache pits were present but no house remains (Hurt, 1961). Coll. 1961 by Mike McCurry; subm. by W. R. Hurt, Univ. Mus., Indiana Univ. Comment (W.R.H.): sample assoc. with typical Late Woodland sherds, such as Scalp wares, found in sites extending S-ward from middle Missouri into N central Nebraska (Gant, 1967).

\section{Tom Pound Ranch site series, New Mexico}

Mammoth bone and tusk from Tom Pound Ranch site $\left(34^{\circ} 26^{\prime}\right.$ $\mathrm{N}$ Lat, $105^{\circ} 46^{\prime} \mathrm{W}$ Long), SE/Y, NW/Y, NE/Y, Sec. 33, T.3N, R.11E, Torrance Co., New Mexico. Samples occurred in "Big Sink" clay, a sandy, white calcareous and gypsiferous deposit, laid down in Pleistocene Lake Estanica. Coll. 1965 by T. R. Lyons; subm. by J. M. Campbell, Univ. of New Mexico. 
M-1764. Tom Pound Ranch site

Sample 4.

M-1765. Tom Pound Ranch site

Sample 5.

General Comment (J.B.G.): dates are too late for mammoth at this location.

Hidden Valley site series, Montana

Black, humic deposit, containing decayed vegetal material, from Hidden Valley site (24 Pw 340) (46 $46^{\prime} 40^{\prime \prime} \mathrm{N}$ Lat, $112^{\circ} 40^{\prime} 42^{\prime \prime} \mathrm{W}$ Long), SE 1/4, Sec. 14, Twp. 11 N, Range 9 W, Powell Co., Montana. Coll. 1967 by C. A. Stevens and P. M. Hobler; subm. by P. M. Hobler, Simon Fraser Univ., Burnaby, British Columbia.

M-1973. Hidden Valley site

$9620 \pm 330$

Feature 1, lowest of 3 humic levels.

7670 B.c.

\section{M-1974. Hidden Valley site}

$9200 \pm 300$

Feature 4, lowest of 3 thin humic levels.

General Comment (P.M.H.): dates are from organic material in a pond deposit. Cultural material was found throughout deposit to almost 2-m depth. Lusk-type projectile points were found in upper portion of deposit stratigraphically above dated unit. Dates seem consistent with cultural and stratigraphic data.

\section{Mexico, Central America, South America}

\section{La Lagunita site series, Mexico}

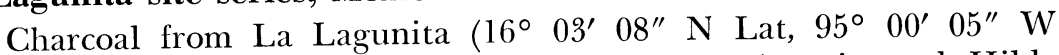
Long), Juchitan, Oaxaca, Mexico. Coll. 1963 by Agustin and Hilda Delgado; subm. by Agustin Delgado, San Luis Potosi, Mexico.

\section{M-1771. La Lagunita}

$1920 \pm 140$

Wood charcoal from Pit 6, Level 10, NE corner, $2.5 \mathrm{~m}$ depth. ProtoZapotec culture, Middle Preclassic.

\section{M-2080. La Lagunita}

$1750 \pm 120$

$$
\text { A.D. } 200
$$

Wood charcoal from Pit 6, Level 10, $2.5 \mathrm{~m}$ depth. Proto-Zapotec culture, Middle or Late Formative. Comment (A.D.): expected date: ca. 400 B.c.

\section{M-1773. Medidas de Bixa'ana, Mexico}

$2080 \pm 140$

Wood charcoal from Medidas de Bixa'ana ( $16^{\circ} 03^{\prime} 02^{\prime \prime} \mathrm{N}$ Lat, $95^{\circ}$ 02' 03" W Long), Tehuantepec, Oaxaca, Mexico. Sample from Pit 3, 
Level 10, $2.5 \mathrm{~m}$ depth. Should date Early or Middle Preclassic. Coll. 1963 and subm. by Agustin Delgado. Comment (J.B.G.): date is later than expected.

\section{M-1774. Ti Pin site, Mexico}

Wood charcoal from Ti Pin site $\left(16^{\circ} 01^{\prime} 09^{\prime \prime} \mathrm{N}\right.$ Lat, $94^{\circ} 09^{\prime} 08^{\prime \prime} \mathrm{W}$ Long), San Mateo del Mar, Tehuantepec, Oaxaca, Mexico. Sample from Hearth No. 2, 0 to $10 \mathrm{~cm}$. Coll. 1963 and subm. by Agustin Delgado. Comment (A.D.): date seems satisfactory.

\section{M-1993. Panuco site, Mexico}

$3950 \pm 180$

Charcoal from Panuco site $\left(22^{\circ} 04^{\prime} \mathrm{N}\right.$ Lat, $98^{\circ} 11^{\prime} \mathrm{W}$ Long), Veracruz, Mexico. Sample from Site 2R, FN 33, Feature 2, prehistoric pottery stove or kiln, 2nd estufa found in pre-Columbian archaeologic context. Chronologic position would be Panuco IV based on Ekholm-McNeish scheme. Coll. 1967 and subm. by A. R. Kelly, Dept. Anthropol., Univ. of Georgia, Athens, Georgia. Comment (A.R.K.): date is much earlier than expected.

\section{Ajijac series, Mexico}

Charcoal from site PN. 6 just $\mathrm{W}$ of village of Ajijac, on $\mathrm{N}$ shore of Lake Chapala, Jalisco, Mexico, in Puerta Nueva region. Site is ca. $11.2 \mathrm{~km} \mathrm{~W}$ of town of Chapala $\left(20^{\circ} 20^{\prime} \mathrm{N}\right.$ Lat, $103^{\circ} 10^{\prime} \mathrm{W}$ Long). Samples from the same stratigraphic levels in 2 different test pits at site. Coll. by M. N. Bond; subm. by D. S. Phelps, East Carolina Univ., Greenville, North Carolina.

\section{M-2437. Ajijac}

General level, $1.80 \mathrm{~m}$ depth.

\section{M-2438. Ajijac}

Test pit G, 1.95 to $2.10 \mathrm{~m}$ depth, "garbage pit" with heavy accumulation of sherds.

General Comment (M.N.B.): 1st analysis of material assoc. with samples indicated levels should be correlated with Chapala phase of $S$ basin of Lake Chapala. But further study indicates levels should be assigned to later Santa Cruz phase; dates $510 \pm 200$ and $510 \pm 100$ (A.D. 1440) support this tentative dating. Assoc. cultural remains, however, suggest levels probably belong to early part of Santa Cruz phase, ca. A.D. 1100 or 1200, rather than as late as A.D. 1440 .

\section{M-2442. Kaminaljuyu site, Guatemala}

$1730 \pm 130$

Sample from Kaminaljuyu site $\left(16^{\circ} 19^{\prime} \mathrm{N}\right.$ Lat, 90 $0^{\circ} 45^{\prime} \mathrm{W}$ Long), Valley of Guatemala, Guatemala. Sample No. KJ68-1786; Zone Area Sec. 46-22-090, Sq. NL, Feature 36, Level 13, Elite residence platform. Assoc. with obsidian specimens dated by obsidian hydration. Coll. 1968 
by J. W. Michels and W. T. Sanders; subm. by J. W. Michels, Pennsylvania State Univ., University Park, Pennsylvania. Comment (J.W.M.): dates one of occupational phases of a Terminal Formative elite residence platform (Mound B II 1). Provisional hydration rate for Kaminaljuyu (7.09 $\mathrm{mu}^{2} / 1000 \mathrm{yr}$ ) suggests $1 \sigma$ standard deviation below the mean represents actual time of occupancy (A.D. 90 to 220), based on obsidian dating of 4 obsidian artifacts in direct assoc. with $\mathrm{C}^{14}$ sample.

\section{M-1639. Juella site, Argentina}

A.D. 1320

$630 \pm 120$

Wood from Juella site, Prov. Jujuy, Argentina, from room No. 21, Unit 20 to 22, in cist with skeleton of adult. Assoc. with 3 types of pottery: Tilcara Black on Red, Angosto Chico Invised, Hernillos Black on Red. Pottery belongs to Humahuaca culture and will be 1st absolute date on this culture. Coll. 1964 and subm. by A. R. Gonzales, Mus. de La Plata, La Plata, Argentina. Comment (A.R.G.): date is satisfactory.

\section{Europe and Near East}

\section{Tell er-Rumeith site series, Jordan}

Charcoal from Tell er-Rumeith site $\left(32^{\circ} 32^{\prime} 51^{\prime \prime} \mathrm{N}\right.$ Lat, $36^{\circ} 00^{\prime} 31^{\prime \prime}$ E Long), Jordan. Syrian Iron Age pottery of this area has not been extensively dated or published. Pottery from 4 distinct strata within period provided evidence of typologic development. Detailed literary and historic documents have been correlated with stratigraphy, but assessment with $\mathrm{C}^{14}$ dates is needed. Coll. and subm. by P. V. Lapp, Pittsburgh Theological Seminary, Pittsburgh, Pa.

M-2028. Sample No. 1

$2860 \pm 160$

910 B.C.

From burnt debris on cobbled floor of gateway of Stratum VIII. Floor laid upon thin makeup set up bedrock. Floor cut by construction trench for Syrian fort wall Stratum VII. Burnt debris dates destruction of VIII. Est. date: \pm 900 B.c.

M-2029. Sample No. 2

$2420 \pm 140$

470 B.c.

From posts used in mudbrick wall rebuilt in Stratum VII and destroyed by fire at end of period. Est. date by typology and history: \pm 850 B.C.

M-2030. Sample No. 3

From posts in fallen mudbrick superstructure of Stratum VII. Syrian fort wall of same destruction as Sample 2.

M-2031. Sample No. 4

$2530 \pm 150$

580 B.c.

From posts of Stratum VIII. Brick fort wall superstructure destroyed at end of Stratum VII as Samples 2 and 3. 
M-2032. Sample No. 5

$2610 \pm 150$

660 B.C.

In layer of burnt brick destruction upon Stratum VI floor of domestic room; dates Stratum VI destruction. Est. typologic date: \pm 800 B.C.

\section{M-2033. Sample No. 6}

$$
2820 \pm 150
$$

870 B.C.

From burnt debris on flagstone floor of cistern court probably reused in Stratum VI just outside Stratum VII defense line.

M-2034. Sample No. 7

$2800 \pm 150$

850 в.c.

From burnt debris E end of Stratum V kiln fire box; end of Stratum $\mathrm{V}$ set by typologic-historic correlation: 732 B.c.

\section{M-2035. Sample No. 8}

$2130 \pm 140$

From burnt debris of floor of house destroyed at end of Stratum V. General Comment (Howard Jamieson): the 2 terminal dates reported in radiocarbon studies agree with tentative conclusions of excavators. Both reports date occupation at bed rock to 10th century B.C. and most recent material is dated to 2nd century B.c. Separation of strata by pottery typology and architectural features is not closely supported by radiocarbon studies, but general scheme agrees well with these studies. Radiocarbon studies of material established date which agrees with typologic data. Destruction at Tell er-Rumeith was massive; thus, materials were understandably concentrated and dispursed by later occupations. M-2029 is only date that does not fit.

\section{Korucutepe site series, Turkey}

Charcoal from Korucutepe (38 $42^{\prime} \mathrm{N}$ Lat, $39^{\circ} 30^{\prime}$ E Long), 30 km E of Elazig, Turkey (Mellink, 1969, p. 210-211). Subm. by M. N. van Loon, Oriental Inst., Univ. of Chicago, Chicago, Illinois.

\section{M-2376. Korucutepe}

$3900 \pm 170$

Operation O 11, Area 1, Level 5, $+827.87 \mathrm{~m}$. Beam lying immediately inside doorway of burned house, with carbonized branches and pieces of roof. House contains plastered hearth platform and "black burnished" pottery typical of East Anatolian Early Bronze Age culture, specifically of Early Bronze II phase. Estimated date: ca. 2600 to 2300 B.C. Coll. 1968 by Juris Zarins. Comment (M.N.vL.): even $1950 \pm 170$ $=2120$ B.c. seems too late, but with MASCA tree-ring correlation of +400 we get 2350 B.c. \pm 170 , which seems correct.

\section{M-2377. Korucutepe}

$3060 \pm 150$

Operation O 21, NE, Level 2, Pit B. Elev.: $+827.47 \mathrm{~m}$. Sample from set of pits containing Late Bronze Age "orange wheel-marked" pottery 
and hieroglyphic seal impressions as found at Bogazköy and other Hittite sites. Estimated date: ca. 1250 to 1200 B.c. Coll. 1968 by M. K. Buccellati. Comment (M.N.vL.): Hittite Empire was destroyed ca. 1175 B.c., so 1110 B.c. seems too late, but MASCA tree-ring correction gives $1110+$ $100=1210 \pm 150$ B.C., which seems correct.

\section{M-2420. Gar-i-Gur, Iran}

$100 \pm 100$

Wood fragments from Gar-i-Gur cave $\left(32^{\circ} 44^{\prime} \mathrm{N}\right.$ Lat, $47^{\circ} 16^{\prime} \mathrm{E}$ Long), Deh Luran, Kermanshah Prov., Iran. Sample is from lowest exposed layer of dry deposit. Deposit is several $\mathrm{m}$ thick and middle layers contained an Islamic jar handle. Coll. 1968 and subm. by H. T. Wright, Mus. Anthropol., Univ. of Michigan. Comment (H.T.W.): interesting cloth and wooden artifacts are apparently quite recent.

\section{Walanczow site series, Poland}

Decomposed peat with some pieces of charcoal from Walanczow site $\left(50^{\circ} 56^{\prime} \mathrm{N}\right.$ Lat, $18^{\circ} 51^{\prime} \mathrm{E}$ Long), near Klobuck, Katowice Prov., S Poland. Coll. 1969 and subm. by Magdalena Ralska-Jasiewiczowa, Inst. Bot. Polish Acad. Sci., Krakow, Poland.

\section{M-2263. Walanczow}

Sample from wall of pit made approx. in center of peat bog, 35 $\mathrm{cm}$ below surface. Should date beginning of Sub-Atlantic period.

\section{M-2264. Walanczow}

$6860 \pm 240$

Sample from wall of pit made approx. in center of peat bog, 50 $\mathrm{cm}$ below surface. Should date fall of sub-Boreal period.

General Comment (S. Milisauskas): M-2263 seems satisfactory; M-2264 is probably too high.

\section{M-2265. Czajkow 2/II, Poland}

$11,930 \pm 400$

Peat from bog from Czajkow (50 $35^{\prime} \mathrm{N}$ Lat, $21^{\circ} 10^{\prime} \mathrm{E}$ Long), near Staszow, Kielce Prov., Poland. Sample from approx. center of bog, 5.00 to $5.10 \mathrm{~m}$ below surface. Should date Younger Dryas and Karst phenomenon in S Poland. Coll. 1967 by Kazimierz Szaepanek; subm. by Magdalena Ralska-Jasiewiczowa. Comment (S. Milisauskas): date seems satisfactory. 


\section{REFERENCES}

Adams, R. McC., 1941, Archaeological investigations in Jefferson County, Missouri 1939-1940: Acad. Sci. St. Louis Trans., v. 30, no. 5, p. 151-221. 1949, Archaeological investigations in Jefferson County, Missouri: Missouri Archaeologist, v. 11 , nos. 3, 4, p. 1-72.

Anderson, J. H., 1970, a geobotanical study in the Atlin region in northwestern British Columbia and south-central Yukon Territory: Ph.D. dissert., Michigan State Univ.

Baby, R. S., Potter, M. A., and Mays, A., Jr., 1966, Exploration of the O. C. Voss Mound, Big Darby Reservoir area, Franklin County, Ohio: Papers in Archaeol., no. 3, Ohio Historical Soc., Columbus.

Brannon, H. R., Jr., Daughtry, A. C., Perry, D., Simons, L. H., Whitaker, W. W., and Williams, M., 1957, Humble Oil Company radiocarbon dates I: Science, v. 125, p. $147-50$.

Broecker, W. S., Kulp, J. L., and Tucek, C. S., 1956, Lamont natural radiocarbon measurements III: Science, v. 124, p. 154-65.

Brown, J. A., 1966, Spiro studies, v. 1, Description of the Mound Group: Univ. of Oklahoma Research Inst.

1967, New radiocarbon dates from the Spiro Site: Oklahoma Anthropol. Soc. Bull., v. 15, p. 77-80.

Broyles, B. J., 1971, The St. Albans Site, Kanawha County, West Virginia: second prelim. rept.: Archaeol. Inv. Rept. \#3, West Virginia Geol. and Econ. Survey, Morgantown.

Crane, H. R., 1961, The $\mathrm{CO}_{2}-\mathrm{CS}_{2}$ Geiger counter: Rev. Sci. Instruments, v. 32, p. 953-962.

Crane, H. R. and Griffin, J. B., 1958, University of Michigan radiocarbon dates II: Science, v. 127, p. 1098-1105. p. 31-48. p. $61-114$.

1968, University of Michigan radiocarbon dates XII: Radiocarbon, v. 10, p. $61-114$. p. $161-180$. p. $155-194$.

University of Michigan radiocarbon dates XIII: Radiocarbon, v. 12

1972, University of Michigan radiocarbon dates XIV: Radiocarbon, v. 14,

Ford, J. A. and Webb, C. H., 1956, Poverty Point, a Late Archaic Site in Louisiana: Anthropol. Papers Am. Mus. Nat. History, v. 46, pt. 1.

Gant, R. D., 1967, Report of the archaeological investigations at the Arp site, 39 BR 101, Brule County, South Dakota 1961: Archaeol. Studies Circ. no. 12, W. H. Over Dakota Mus., Univ. South Dakota.

Griffin, J. B., 1946, Cultural change and continuity in eastern United States, in: Man in Northeastern North America, Andover, Mass., p. 40.

Grolier, M. J. and Detwyler, T. R., 1970, The Grand Sable Dunes, Michigan; pre-flight investigations for remote sensing: U.S. Geol. Survey (Flagstaff, Ariz.) open file rept., 147 p.

Hurt, W. R., 1961, Archaeological work at the Tabor and Arp sites: Mus. News, W. H. Over Mus., Univ. South Dakota, v. 22, no. 1 .

LaSalle, P., 1968, Field trip of Quaternary geology, Saguenay River-Lac St. Jean, 6-7 Sept. 1968: Quebec Dept. Nat. Resources, 31 p.

LaSalle, P. and Rondot, J., 1967, New $C^{14}$ dates from the Lac St. Jean area, Quebec: Canadian Jour. Earth Sci., v. 4, p. 568.

Lietzke, D. A. and Whiteside, E. P., 1967, Comparison of Podsol soils in northern Michigan with Nunatak soils in a sub-arctic maritime climate: Michigan Acad. Arts, Sci., and Letters, Ann Arbor, Mich.

Lilly, E., 1963, Prehistoric antiquities of Indiana: Indianapolis, p. 68-71.

Mellink, M. J., 1969, Archaeology in Asia Minor: Am. Jour. Archaeol., v. 73, p. 203-27.

Miller, M. M., 1966, Progress rept., Nat. Geog. Soc. Alaskan Glacier commemorative proj., summer phase, 1966.

Orr, K. G., 1952, Survey of Caddoan area archaeology, in: J. B. Griffin (ed.), Archaeology of the eastern United States, p. 239-255.

Redding, T. B., 1892, The Prehistoric earthworks of Henry County: Indiana Acad. Sci. 1891 Proc., v. 2. 
Scholtz, J. A., 1968, The Dumond site (3 AR 40): The Arkansas Archaeologist, v. 9, nos. 1-2, p. 10-27.

Shay, C. T., 1963, A preliminary report on the Itasca Bison site: The Minnesota Acad. Sci. Proc., v. 31, no. 1, p. 24-27.

_ 1971, The Itasca Bison Kill site, an ecological analysis: Minnesota Historical Soc., St. Paul, Minnesota.

Strickler, W. C. and Wilson, D. C., 1967, Mound Four, West, New Castle site, in: Archaeol. Rept., no. 2, Ball State Univ., p. 2-10.

Stuiver, Minze, 1969, Yale natural radiocarbon measurements IX: Radiocarbon, v. 11, p. $545-658$

Swartz, B. K., Jr., 1966, Field reports, first annual Ball State Univ. summer field school: Archaeol. Repts., no. 1, Ball State Univ.

1970, A radiocarbon date from the Van Nuys site: B. K. Swartz, Jr., (ed.), Archaeolog. Repts., no. 6, Ball State Univ., p. 15.

USDA-SCS, 1960, Soil classification-a comprehensive system-7th approximation: Soil Survey Staff, USDA-SCS.

Valastro, S., Jr. and Davis, E. M., 1970, University of Texas at Austin radiocarbon dates VIII: Radiocarbon, v. 12, p. 617-639. 